\title{
From Smart Cities to Experimental Cities?
}

\author{
Dr. Igor Calzada, MBA \\ University of Oxford, Urban Transformations \\ igor.calzada@compas.ox.ac.uk \\ @icalzada
}

Calzada, (2017), From Smart Cities to Experimental?, in Co-Designing the Economies in Transition: Radical Approaches in Dialogue with Contemplative Social Sciences, eds. Vincenzo Mario Bruno Giorgino and Zachary David Walsh (London, UK: Palgrave Macmillan). 


\section{Introduction: Transitions from the Smart Cities to Experimental Cities}

It is noteworthy that although smart cities (Albino, Berardi, \& Dangelico, 2015; Ersoy, 2017; Krivy, 2016;) are already being built around us, they differ considerably from the simplistic, one-size-fits-all, smart-city-in-the-box approach that has thus far dominated mainstream institutional approaches. Hence, we could ask for whom and for what purpose smart cities are being developed? Are smart cities primarily about, or should they be about: a) creating new markets and profit, b) facilitating state control and regulation, or c) improving the quality of life while enhancing levels of democracy with citizens?

The contemporary smart city cannot simply be reduced to the economic value generated by partnerships involving powerful public and private actors (Rossi, 2015). While attention to the application of new information flows and the development of socalled smart cities is increasing, there is still limited understanding of the interconnections among hard and smart infrastructures and economic, political, and social systems on metropolitan and regional scales. Furthermore, this conventional paradigm has often failed to deliver practical tools that can help us to better understand and intervene in our daily realities, while also engaging with the various stakeholders that are important for our cities and regions. Hence, a multi-stakeholder approach is required to overcome dataism (Harari, 2016), understood as the logic that simplifies city metabolisms as merely assemblages or systems of data and algorithms (Finn, 2017; Morozov, 2014; Morozov \& Harvey, 2016; Morozov \& Bria, 2017; Morozov \& Eno, 2017), rather than ecosystems of citizens (Keith \& Calzada, 2016; Kontokosta, 2016).

It could be argued then that the development and use of the buzzword smart city in planning inner cities is intimately connected to currently required urban 
transformations (Calzada, 2016). There is currently a great deal of rhetoric about the importance of building smart cities which do not pay attention to elements that constitute smart city strategies and policies in diverse contexts (Kitchin, 2016). Technological solutions have often been proposed under the umbrella of the smart city buzzword without first considering citizens' needs, their ability to use them, or their socio-technical misalignment within the city itself (Hajer et al., 2014; Campbell, 2012).

Thus, this chapter suggests that we should first unplug, unpack, and deconstruct the meaning of smartness in our unique urban realities (Calzada \& Cobo, 2015) by asking ten underlying questions about the city we want to make. As such, there are ten transitions we are able to adopt from the so-called smart cities approach to apply to a new paradigm that this chapter will explain in the section on experimental cities. Here are the ten transitions and questions for unpacking the smart city:

1. Who: Will the smart city evolve into an urban sphere in which dwellers have the right to decide whether to be connected?

2. How: Is the city a social interface in which the citizens will be able to selfdesign their social, everyday life needs?

3. System: Will these devices serve the citizens more than the citizens will serve the devices?

4. Governance: Is the bottom-up innovation perspective simply wishful thinking?

5. Information: In the era of data, is it possible to transition from controlled to open data-driven models?

6. Focus: Do we notice the difference between simple social interactions and human ties built on trust? 
7. Space: Will we observe changes in which context-collapsed information will be contextualized to enhance social interactions? What are the implications for the privacy and security of individuals (Forbes, 2016; CNN, 2016)? Context collapse is a term used by academics (Marwick \& Boyd, 2010) writing about the effects of social media and the contexts they give rise to. As such, referring to an infinite number of contexts collapsing upon one another into that single moment of recording and having direct consequences in the public and private life of citizens.

8. Design: How can the design of places and user interactions be improved to anticipate an ambient commons for citizens? The 'ambient commons' term (McCullough, 2013) claims for a cognitive role for citizens around the fixed forms of architecture and the city itself, surrounded by a superabundance flow of ambient information where individual signals increasingly matter less.

9. Socio-political processes: Is a shift occurring in the power dynamics between stakeholders?

10. Political economy: Will the political economy of the smart city be altered by any changes in stakeholder power relations?

It will be just after unpacking the technodeterministic view in our cities (unplugging) when we can connect (plug) stakeholders into a wide, smart governance framework by including five type of actors, which this chapter presents later in the Penta Helix model (Calzada, 2016; 2017). These actors include the public sector, the private sector, academia, civic society, and social entrepreneurs. Indeed, it is necessary to plug stakeholders in by setting up a new complex, multi-stakeholder, city-regional urbanity to transit towards real smartness in cities and regions. A lack of dynamic power 
balance between stakeholders has so far been present in the hegemonic and technocratic version of the smart city.

However, the position outlined in this chapter avoids a dystopian view by embracing a constructive notion that considers the favourable conditions that exist for a potential critical politics of a smart city policy agenda based on urban transformations driven by social innovation and experimentation. Likewise, cities and regions represent, as such, powerful places in which to detect emerging processes and observe spontaneous urban transformations. To summarize, after minimizing the negative side-effects of hyperconnected societies, technology-oriented pathways of smart cities offer still unexplored opportunities for experimentation. We should embrace transitional experiments in our cities and regions as they exist in places like Dublin, Bristol, Barcelona, Torino, Amsterdam, Bilbao, and Glasgow (Calzada, 2017a).

As a result of these ten transitions from the smart city to the experimental city paradigm, there are three open research questions that relate to the core theme of this publication on radical approaches in dialogue with contemplative social sciences (Giorgino, 2014):

1. What prospects are there for alternative funding and alternative business models for smart cities?

2. What are the necessary practical/political interventions among businesses, local governments, academia, communities, and social entrepreneurs?

3. Is another type of smart city possible; that is, a third-way between state and market overcoming the public-private partnership (PPP)?

At the end of this chapter, the answers to these three questions will be explored. 


\section{Smart Citizens: Decision Makers more than Data Providers}

In this context, we could ask whether or not alternatives to the technodeterministic approach to smart urbanism (Marvin, Luque-Ayala, \& McFarlane, 2016) are flourishing. In fact, attention to a new way to empower the smart city by its smart citizens has been increasing in the last few years (Waag, 2013; Hemment \& Townsend, 2013). These days, cities such as Barcelona are embracing this new shift to an inclusive, democratic, and participative smart city by advertising accordingly: "If you'd rather have smart citizens than smart cities... BITS will be in your interest” (BITS, 2016).

Those advocating for smart citizens (Waag, 2013) in a recent manifesto suggest that smart citizens: take responsibility for the places they live, work, and love in; value access over ownership, contribution over power; ask for forgiveness, not permission; appropriate technology, rather than accept it as is; and provide assistance to those who are less tech savvy. This set of principles underlies the notion that there is still a limited understanding of the interconnections between hard and smart infrastructures, as well as between economic, political, and social systems on metropolitan and regional scales. Furthermore, this new paradigm suggests the importance of overcoming the often failed smart-city-in-the-box approach by engaging with the various stakeholders that are important for our cities and regions.

Hence, this chapter aims to rethink the dominant technocratic and technologycentric smart city discourse by presenting this new take on so-called smart citizens. The new approach focuses not on imagining cities beyond or before technologies, but on accepting that city-regions are already fundamentally shaped by networked and mobile ICTs (Information Communication Technologies) and by critically thinking through the consequences for governance that the promises and realities of smart cities pose. For 
example, many argue that smart city-regions will inevitably revolve around generating large amounts of data and that this in itself will lead to new insights and governance strategies. But in reality, city-regions are much more complex and shaped by a large variety of different actors and organizations with often conflicting positions (Calzada, 2015). Likewise, data generated about individuals in cities and regions are variable, including personally identifiable information, data exhaust, personal data trails, and participatory personal data. As such, 'data about people is big data in both the cognitive sense and social movement sense' (Shilton, 2016, p. 21). Actually, not all big data is data about people, but data about people inspire much of the hope and anxiety of their material, emotional and relational human conditions in an individual and collective way.

Another strand of debate emphasizes the impact of the near-universal uptake of smartphones and other hand-held devices as well as the impact of the internet of things -i.e., networks of data-gathering and cloud computing (Ratti \& Claudel, 2016). Many people use these devices and networks on a daily basis, but what this means for cityregional governance and the power-laden relationships between citizens, governments, and companies remains an open question. All this makes truly smart city-regional governance (Herrschell \& Dietwchter, 2015) exceedingly difficult, but at the same time a fascinating and rewarding scale for investigating the various meanings and usages of smartness.

Recently, various research projects across Europe have started investigating these issues related to the notion of smart citizens. Most seek to develop not just critical analyses, but also practical suggestions to tackle urban problems such as pollution, health, safety, or mobility through the development and use of various types of mobile and networked data. These projects all revolve around the interlinked notions of smart citizens and data insofar as the so-called smart city approach has been elaborated on the 
ground by taking for granted the various ways to consider this binary combination. Specifically, the research efforts sought to unpack and question the following:

1. the kinds of knowledge gained through the production, distribution, and use of smart data;

2. the role data plays in the constitution of urban expertise and in mediating and transforming the relationships between smart citizens, governments, and companies; and

3. the ways in which data-driven knowledge and expertise tackles and/or reproduces inequalities in city-regions among diverse group of (smart) citizens by provoking social exclusion patterns driven by technological toxic side-effects (Hughes, 2016).

By finding answers to these questions, it is clear that aspects such as the technopolitics of data and how smart citizens should be integrated into this realm of governance remains crucial (Calzada, 2017a; Gray \& Lämmerhirt 2017). Indeed, as the smart city approach is being deconstructed from many instances after recently saturating policy agendas with very little reflexivity and being driven by market-based urban solutions, a new smart-citizen-centric paradigm is being tested. These urban experiments are intriguing; 'their actuality matters in producing a different kind of city by offering novel modes of engagement, governance, and politics' that both challenge and complement conventional strategies such as on-going smart city strategies (Evans, Karvonen, \& Raven, 2016, p. 9).

We therefore should explore what is new in the experimental city approach compared to the smart city approach. In an attempt to make this contrast and trace the evolution from one paradigm to the other, the following table shows 14 changing dimensions: 


\begin{tabular}{|c|c|c|}
\hline Dimension & Smart Cities & Experimental Cities \\
\hline 1. Data Techno-politics & Big Data & Co-production of Open Data \\
\hline 2. Notion of the City & $\begin{array}{l}\text { As a Market (European } \\
\text { Commission-H2020, 2017) }\end{array}$ & $\begin{array}{l}\text { As a Platform (Anttiroiko, } \\
\text { 2016) }\end{array}$ \\
\hline 3. Data Ownership & Privately owned & Publicly scrutinized \\
\hline 4. Stakeholder Helixes & Triple or Quadruple & Penta (Calzada, 2017b) \\
\hline 5. Business Models & Public-Private Partnership & Urban Commons \\
\hline 6. Smart Citizen & User/Data Provider & Decision Maker \\
\hline 7. Replicability & Based on Urban Solutions & Unpacking Urban Problems \\
\hline 8. Disciplinary & Monodisciplinary & Inter-disciplinary \\
\hline 9. Environment & IoT Sensor Networks & Citizen Sensing \\
\hline 10. Waste* & \multicolumn{2}{|c|}{$\begin{array}{c}\text { Compactor Bins } \\
\text { Dynamic Routing/Collection }\end{array}$} \\
\hline 11. Energy* & $\begin{array}{r}\text { Sm } \\
\text { Sma } \\
\text { Energy } \\
\text { Sma }\end{array}$ & $\begin{array}{l}\text { Grids } \\
\text { Meters } \\
\text { age Apps } \\
\text { ighting }\end{array}$ \\
\hline 12. Transport* & $\begin{array}{r}\text { Intelligent T } \\
\text { Integra } \\
\text { Smart } \\
\text { Bi } \\
\text { Real-time } \\
\text { Sma } \\
\text { Logistic } \\
\text { Tran }\end{array}$ & $\begin{array}{l}\text { Tickort Systems } \\
\text { vel Cards } \\
\text { share } \\
\text { ssenger Info } \\
\text { arking } \\
\text { lanagement } \\
\text { rt Apps }\end{array}$ \\
\hline
\end{tabular}




\begin{tabular}{|l|l|l|}
\hline \multirow{2}{*}{ 13. Government } & \multicolumn{2}{|c|}{ Dynamic Road Signs } \\
& E-government Systems & Niche Experiments \\
& Online Transactions & Online Decision Making \\
& City Operating Systems & Open Platforms \\
& Performance Management & Dynamic Management \\
& Urban Dashboards & Urban Living Labs \\
\hline 14. Causality & Linear: Cause \& Effect & Complex Adaptive Systems \\
\hline
\end{tabular}

Table 1. From Smart Cities to Experimental Cities. (Elaborated by the author)

As a consequence of the information provided in the table 1, we could argue that smart citizens are becoming the center of current smart city transformations (Satyam \& Calzada, 2017) by emphasising three achievements of urban laboratories as the new experimental settings (Karvonen \& van Heur, 2014): situatedness, change-orientation, and contingency. The technical domains such as waste, energy, and transport (marked with an ${ }^{*}$ ) could still be in both approaches because of the very limited data impact study so far in a given territorial domain. As such, data science could enable-or not enable - citizens' advice to anticipate or even predict changes in the issues affecting people everyday, to act sooner to prevent problems from escalating (NESTA, 2015; Gray \& Lämmerhirt, 2017).

In a nutshell, (smart) citizens (Noveck, 2015; Thomas, Wang, Mullagh, \& Dunn, 2016; Schuurman, De Marez, \& Ballon, 2016) are considered decision makers rather than simple data providers insofar as their decision will depend on a relational context and the unique circumstances. Currently, in the scope of some experimental city approaches being carried out under the umbrella of the urban living labs methodologies (Casual, 2016; Keith \& Headlam, 2016; Leminen, 2015; Almirall \& Wareham, 2011), 
participants play more of an active role as citizens as co-producers than mere data providers, though there is unexplored research terrain regarding the techno-politics of data (NESTA, 2015), namely its ownership and governance.

\section{Techno-politics of Data}

According to Gartner (2016), 1.6 billion devices will be connected to the larger smart city infrastructure worldwide by the end of 2016. However, as was highlighted in previous sections of this chapter, some uncertainties remain at the center of the debate around what Yuval Noah Harari has described as dataism (2016). What do we mean when we talk about smart citizens in the age of Big Data? According to Shilton (2016, p. 21), 'uncertainties about how to use increasingly large sets of personal data are at the center of social debates about the virtues of Big Data. Not all big data is data about people, but data about people inspire much of the hope and anxiety bound up in discussions of the term.' Who controls data collection, analysis, storage, and usage? These are key questions regarding the techno-politics of data for our present cities:

\begin{tabular}{|c|c|c|c|c|}
\hline $\begin{array}{l}\text { Techno-politics } \\
\text { of data }\end{array}$ & Collection & Analysis & Storage & Reuse \\
\hline $\begin{array}{l}\text { High } \\
\text { participation }\end{array}$ & $\begin{array}{l}\text { Subjects own } \\
\text { or control } \\
\text { devices; } \\
\text { collection can } \\
\text { be customized }\end{array}$ & $\begin{array}{l}\text { Raw data } \\
\text { accessible; } \\
\text { subjects can } \\
\text { conduct their } \\
\text { own analyses }\end{array}$ & $\begin{array}{l}\text { Data stored on } \\
\text { local devices }\end{array}$ & $\begin{array}{l}\text { Individuals } \\
\text { control reuse }\end{array}$ \\
\hline $\begin{array}{l}\text { Low } \\
\text { participation }\end{array}$ & $\begin{array}{l}\text { Subjects aware } \\
\text { of devices; }\end{array}$ & $\begin{array}{l}\text { Subjects can } \\
\text { see }\end{array}$ & $\begin{array}{l}\text { Data in cloud } \\
\text { storage with }\end{array}$ & $\begin{array}{ll}\text { Reuse } & \text { is } \\
\text { restricted to }\end{array}$ \\
\hline
\end{tabular}




\begin{tabular}{|c|c|c|c|c|}
\hline & $\begin{array}{l}\text { collection can } \\
\text { be avoided }\end{array}$ & $\begin{array}{l}\text { visualizations } \\
\text { or analysis of } \\
\text { their data }\end{array}$ & $\begin{array}{l}\text { options for } \\
\text { deletion }\end{array}$ & $\begin{array}{l}\text { aggregated } \\
\text { forms }\end{array}$ \\
\hline $\begin{array}{l}\text { Little to no } \\
\text { participation }\end{array}$ & $\begin{array}{l}\text { Subjects } \\
\text { unaware of } \\
\text { devices; } \\
\text { collection } \\
\text { cannot be } \\
\text { avoided }\end{array}$ & $\begin{array}{l}\text { Subjects } \\
\text { evaluated or } \\
\text { categorized } \\
\text { without their } \\
\text { knowledge }\end{array}$ & $\begin{array}{l}\text { Data in cloud } \\
\text { storage with no } \\
\text { option for } \\
\text { deletion }\end{array}$ & $\begin{array}{l}\text { Data collectors } \\
\text { share or sell } \\
\text { data }\end{array}$ \\
\hline
\end{tabular}

Table 2. Techno-politics of Data Collection, Analysis, Storage and Reuse.

(Elaborated by the author from Shilton, 2016, p. 26).

Regarding new sources of data collection, storage, and usage, the major obstacles to fostering a people-centered design of data is presented by the acquisition, shareability, and licensing restrictions of the obtained data. In this respect, there must be a closer collaboration between computer scientists and social and political researchers in developing stronger evidence-based research on how to tackle unexplored data issues. As such, we should elaborate on the need to consider individuals not only as citizens deliberating on their material conditions, but also as consumers agreeing and disagreeing to the particular terms of a service. In a nutshell, we could advocate for a more human-centered approach to the smart city-one that fosters interplay and interdependencies among multiple stakeholders.

When Habermas (2015) confronted technocratic and democratic smartness, he made it possible to generalize a category called smart citizens. As such, citizen interaction, engagement, involvement, participation, and deliberation are at the center of the debates 
around techno-politics of data. However, how should we deal with the lack of trust, apathy, and open outrage that has become increasingly evident in popular political attitudes today? The misalignments between technology and the social needs of citizens in data generation were identified as a common dilemma today: will data-driven cities (PWC, 2016) and devices continue to serve citizens or vice versa? As a consequence, different forms of smart citizens engagement could be discussed regarding the technopolitics of data. As Morozov (2014) has argued, despite the plethora of technological solutions to social problems, key questions remain unanswered: for example, "who gets to implement data?," and "what kinds of politics of data do technological solutions smuggle through the back door?" Discussions highlighting how calls for data to be open, while apparently simple, actually challenge existing legal norms and pose profound implications for users along the chain. For example, liability risks might be passed to the end user of open data, but what if end users cannot bear the risk? If the internet of things (IoT) generates continuous monitoring and commonly individualized data, how should we theorize, regulate, and make visible the ethical choices (Hughes, 2016) that have now emerged around the legal liability surrounding the ownership of data?

For a full understanding of the techno-political implications of the term smart citizens (Noveck, 2015) and to put into practice the whole capacities of citizens as the main driver in urban transformations, this chapter underlines the necessity for a deeper transition towards experimental cities. When citizens are considered users or data providers, it is assumed that personal data comprises a raw material that citizens take for granted as another element of the market. This fact should draw the attention of policy makers insofar as there are underlying issues of value and political decisions involved. 
Citizens own data as an intrinsic part of their urban experience and their right to the city (Morozov \& Harvey, 2016). Why then do we not naturally consider smart citizens to be pure decision makers, rather than just passive data providers? Despite this willingness to pursue sustainable futures that are more democratic, than technocratic, there is still strong inertia resisting this alternative path. Actually, the current round of urban experimentation differs from previous incarnations, indicating a specific kind of governance fix for a neoliberal system that is struggling to move towards more sustainable forms of urban development (Evans et al., 2017, p. 10). Based on Oström's influential thoughts on the commons (Oström, 2010), Subirats (2012) suggests breaking away from the individualistic vision as conceived by the capitalist tradition. Subirats notes that this vision has progressively transferred the idea of rights to individual people. The new prevailing view is that only privatization leads to growth. However, we should also point out the inspiring critique made by Bollier (2016) advocating that historically-rooted individualization processes are increasingly shaping the communal conditions of humans insofar as inter-subjectivity matters between them (Borch \& Kornberger, 2015).

In a serious attempt to transition from the smart city to the experimental city, a deeper analysis of the techno-politics of data will be required to interpret the role of the smart citizens as decision makers rather than data providers. This notion is likely to be influenced by new conceptual explorations and empirical analyses of the urban commons. There are three European projects on participatory smart cities that are important to consider, because they reconceptualize smart citizens as decision makers rather than data providers: HackAIR (2016), Flamenco (Flanders Mobile Enacted Citizen Observatories) (2016), and the City of Things (2016). Together, they mark a 
transition from the smart city to the experimental city by including an analysis of the techno-politics of data.

HackAIR is a social innovation project (Calzada, 2013; Sabato, Vanhercke, \& Verschraegen, 2017) and open technology platform for citizen observatories on air quality. The project focuses on the level of citizen engagement and related strategies, such as crowdsourcing (citizens as sensors), distributed intelligence (citizens as basic interpreters), participatory science (citizens as participants in data collection), and extreme collaborative science (citizens as participants in defining problems and analyzing data). The call to transition from the conception of citizens as data providers to citizens as decision makers provokes a powerful debate on the ethical dimensions of participatory innovative technologies.

The Flamenco project has developed this theme further, exploring how citizens can be empowered to tailor their own observatories based on participatory sensing and citizen science principles. An inter-disciplinary team is working on the applicability of the project from the perspectives of computer science and social science.

The City of Things project explores the experimental dimensions of data-driven living labs. These dimensions are related to multi-stakeholder co-creation processes for business, user design, prototyping, and product development. Basically, these are open innovation processes that aim to connect to user experience along the product design process (West \& Bogers, 2016).

These projects demonstrate that in one sense what was once novel has become received wisdom. It is now common sense to suggest that the nature of the metropolis demands forms of knowledge that transcend old boundaries between the humanities, natural sciences, and social sciences. It has become almost self-evident to assert that a model of knowledge production that is produced upstream in the academy and then 
exported downstream to city hall and local governance structures is inadequate for the metropolitan challenges of the $21^{\text {st }}$ century. Instead, we have moved towards a stronger sense of co-production between research and practice. The sense that the questions arise in the real world but the answers are to be found in the academy is less plausible than ever. At its worst, the smart agenda, particularly as represented by journalistic accounts, can look like a return of technocratic determinism through the back door, whereby all urban ills are resolved through scientific solutions. Such naïve arguments are in reality more often the belief of second-rate technocrats and third-rate academic critique.

More interestingly, we witness a situation where the complex and open systems of urban life are disrupted by rapid social change and powerful economic forces (Keith \& Calzada, 2016). Recognising that such change is unpredictable in its disruptive form and uneven in its social consequences, one function of academic research is to speculate, test, map and trace how disruptive technologies restructure the relationship between the individual and the city. The smart citizen at the heart of the new city needs to understand both the emancipatory potential and the divisive consequences of different moments of disruptive innovation. As we are going to observe in the next section, it is the duty and function of Urban Living Labs (Karvonen \& van Heur, 2014) to surface and make visible the choices at stake, rather than provide singular solutions to problems. How we make these choices then becomes a mediation of scientific expertise and deliberative democracy.

This section highlighted how data-driven issues present new pathways to conduct research and implement policy. However, if we want to unpack data (unplug), we must also more deeply consider the underlying social, ethical, and political implications affected by the technical capacity to store and distribute bits of information through the power of data science. Dystopian visions and technocratic utopias alike demand 
rigorous scrutiny in research and public debate to optimize the chances for shaping a better future city.

Concerning the ethical and political dimensions of the ownership of data, urban experiments are gaining traction in cities all over the world, as a way to stimulate alternatives and steer change. Policy makers, designers, private companies, and third sector organizations are initiating innovations to test alternative visions of local economic development, social cohesion, environmental protection, expansion of the creative sector, the evolution of policy, service delivery, infrastructure provision, academic research, and more. The concept of experimentation feeds on the attractive notions of innovation and creativity (both individual and collective) while reframing the emphasis of sustainability from distant targets and government policies to concrete and achievable actions that can be undertaken by a wide variety of urban stakeholders in specific places. The ability of urban experiments to be radical in their ambition while limited in their scope underpins a vibrant debate in both the policy and academic worlds with respect to their ability to prompt genuine change. Are these activities simply extensions of business as usual, spatially limited, and captured by a familiar cast of dominant interests? Or can they generate real alternatives and stimulate profound transformation? The next section will ruminate on the promises and perils of experimentation, as an increasingly alternative mode of urban governance that is actually moving beyond the structural mistakes of the so-called smart city as the dominant mode. 


\section{Experimenting with the Urban Commons: The Multi-Stakeholder Penta Helix}

\section{Framework}

In smart city and smart specialization strategy $\left(S^{3}\right)$ policy discourses, governance interventions have been proposed in European cities and regions without appropriately considering the stakeholders, their multiple expectations, and their visions for a possible and desirable urban future. As such, smart technological solutions have not always focused on how technologies are used by citizens, and at times, the experimental city's modes of governance have been misaligned with citizens and stakeholders.

In this context, to understand the inter-dependent challenges and opportunities for different stakeholders, we might focus on the dynamics of urban complexity, experimental research, and alternative policy approaches to cities and regions. This section is an invitation to rethink urban Europe around the notion of an experimental laboratory that produces research and policy interventions. Urban Living Labs (ULLs), exemplified by networks such as ENoLL (European Network of Living Labs), foreground projects that present active user involvement, real-life settings, multistakeholder participation, multi-method approaches, and co-creation.

In contrast, the smartness of some European urban strategies is dominated by a technological discourse centered on data aggregation that allows the city-region to be managed by a given and fixed public-private partnership governance model. Nonetheless, the contemporary city cannot be forgotten in the complex multistakeholder context that is flourishing here and there.

Paralleling the mainstream approach of smart cities, urban laboratory initiatives, generally placed under the loose banner of ULLs, have been increasingly emerging over the last few years as an approach to speed up socio-technological innovation involving multi-stakeholders in co-production processes, and as a form of collective urban 
governance and experimentation that addresses the sustainability challenges and opportunities created by urbanization. Currently, what is interesting are the ways that city innovation policies propose highly spatially specific and potentially transformative stakeholder-helix strategies (either triple, quadruple, or penta), which recognize that strategies are cross-sectoral, involving the research base, private capital, and public expenditure of civil society.

The enormous potential for experimental forms of governance in European cityregions is expressed by on-going ULL initiatives such as the Urban Living Partnership (Birmingham, Bristol, Leeds, Newcastle, and York), JPI Urban Europe schemes, and in many international schemes such as ENOLL, Mistra Urban Futures, Urban Mechanics, Guggenheim Urban Labs, Urban Lab +, the Guanghzhou International Award for Urban Innovation, Rockefeller 100 resilient cities, GUST snapshots, urb@exp, and ERC urban.

Building on the emerging body of policy initiatives and research (Keith \& Calzada, 2016), this section addresses how notions of experimentation inform new ways of urban living:

1. What does the integration of inter-disciplinary and place-based knowledge practices mean? How can we bring together expertise in areas such as computing, mapping, politics, economics, digital anthropology, spatial analysis, and urban planning?

2. How can we deal with multi-stakeholder helix strategies? What are the roles of the private sector, public authorities, academia, civil society, and entrepreneurs/activists in these ULL initiatives? What should the roles be?

3. How can ULLs transcend the current governance constraints of the smart specialisation policy agenda in Europe?

4. What makes the ULL approach attractive and novel? 
5. How are ULL initiatives being operationalized in contemporary urban governance initiatives for sustainability and in low carbon cities?

6. What prospects are there for alternative funding and alternative business models for cities and regions in Europe? (Uraia Nicosia Guidelines, 2016)

7. What are the practical and political interventions needed within multistakeholder approaches, and what are the potential concerns about data technopolitics?

8. Is another urban governance model possible - a third-way between state and market? (OECD/KIPF, 2016)

The next section explores the strategic role of institutions in order to foster regional ecosystems of experimentation engaging the public sector, the private sector, academia, civic society, and social entrepreneurs/activists. In this endeavor, five sub-sections will be specified. The first sub-section will elaborate on the notion of experimentalism rather than smartness. The second sub-section will build on how urban governance requires considering the commons beyond public-private partnerships. In the third sub-section, the Penta Helix framework will be presented. The fourth sub-section will describe the city as a platform. Finally, the fifth sub-section will suggest a link between smart citizens as decision makers and as maker citizens.

\section{Experimenting (with the city)}

According to Karvonen \& van Heur (2014), the experimental city approach champions the promise of experimental processes to promote urban innovations related to environmental protection, social cohesion, capitalist expansion, the development of the creative sector, policy improvements, infrastructure provision, academic research, and so on. It is important to recognize that the notion of the experimental city is related 
to a wider discursive field that includes triple helix formations, applied innovation, engaged research, trans-disciplinarity, living laboratories, and the co-production of knowledge. As such, experimental urbanism (Amin \& Thrift, 2016) taps into ideas of urban change as inherently multi-disciplinary, data-intensive, and embedded in place.

Whereas the smart city approach has been forged with an impetus toward urbansolution-driven fixes, the experimental city has been based on three steps that unpack urban practices (Latour, 1983, p. 166): First, social scientists must capture the interests of non-scientists outside of the laboratory (in the field); Second, they must collect information on real-world problems in the field and introduce this information into the controlled conditions of the laboratory to facilitate experimentation; And third, social scientists must extend the laboratory into the wider society by carefully re-introducing the experimental results back into the field.

\section{(Experimenting with the) Urban Commons}

The notion of the commons should be included in this narrative insofar as the smart city rhetoric has been entirely based on the idea of public-private partnerships. In this chapter regarding the techno-politics of data and the transition towards a more experimental city approach, it is important to understand that the debate over the commons coincides with great technological changes that demand and invite us to work both from a scientific perspective to increase the capacity for innovation and crossfertilization, as well as from a social perspective to ensure processes of social change and transformation. The urban commons thus go beyond state-market relations (Subirats, 2012). As such, it is important to revisit one of the first questions from the beginning of this chapter: Is another type of city possible, that is, a third-way between the state and the market, which is not dominated by public-private partnerships? Maybe 
we can see a political ferment gathering around these ever more frequent conflicts that do not find an adequate response in the traditional market-state dichotomy. What would be the answer to this governance need?

Bollier and Helfrich (2016) suggest that cities are at a crossroads insofar as (smart) citizens could use the ideas of the commons to retain control of the services that matter to them and to ensure they work for the people of the city, not just for business or bureaucracy. However, we could also argue that the idea of the urban commons could be rather experimental in its outcomes (Borch \& Kornberger, 2015). At this preliminary stage, there should be an evolution in the urban governance model, by which I mean that there needs to be a necessary transition from the so-called triple and quadruple helixes to the penta helix (Calzada, 2017b). The notion that the experimental city can overcome the limitations of the smart city itself offers us a plethora of strategies to include more voices in the governance equation.

\section{Penta Helix Multi-Stakeholder Approach}

According to Lewontin (2000) and Leydesdorff \& Fritsch (2006), the triple-helix model (made up of private, public, and civil society) enables us to study the knowledge base of an urban economy in terms of civil society's support for the evolution of cities. However, we could also argue that dynamic and pervasive social innovation processes are not included in this analysis. In the context of the experimental city, academia (quadruple helix) and entrepreneurs/activists (penta helix) are required to transition from the smart city approach. The laboratory context of experimenting with the urban commons should reflect a wide range of voices in a certain community, and not be relegated to institutional settings. The inherent instability of an experimentally-driven city provides a mechanism for co-evolution and a capacity to reflexively process the 
transition from the smart city approach. Often, dynamics of social innovation (Calzada, 2013b) are forgotten by those fostering urban change.

\section{City as a Platform}

Another dimension that is related to the experimental city is the understanding of the city as a platform (Anttiroiko, Valkama, \& Bailey, 2013; Anttiroiko, 2016) and as a commons (Foster \& Iaione, 2016). Local authorities provide a wide range of services including users' involvement in product development and citizens' right to bring their concerns to open innovation systems. Forms of participation may vary-some nominal, some transformative. More transformative modes of participation are associated with the opening of public data sets for public use free of charge and are related to open source and user innovation movements. On the whole, they reflect the increasing intersection between the penta helix driven by (social) entrepreneurs/activists and the experimental notion of the urban commons.

To some extent, a balance between private and public interests is complemented by other activities that could be considered the seeds of the experimental city in the realm of the urban commons. As such, there are inherent asymmetries in the level of engagement between firms and citizens that are compensated by welfare structures. Understanding the city as a platform may be a less controversial view of how to legitimize urban laboratories.

\section{Smart Citizens as Maker Citizens}

Finally, in the realm of the experimental city, (smart) citizens should represent a more transformative role as decision makers. In addition, the way in which some cities are evolving towards the power of the maker culture is related to the emergence of 
citizens as makers too. Cities like London have established a network of makers in diverse disciplines (http://openworkshopnetwork.com/), which is surely the source of further experimentation in the city.

\section{Final Remark: Towards Urban Co-operatives?}

This chapter examined the notion of the experimental city as a category that could overcome the smart city by shedding light on its limitations. I attempted to foresee how citizenship could require a more active role, so that citizens become decision makers rather than merely data providers. As such, the era of data and algorithms introduces uncertain ethical and political questions that should be solved in the terrain of techno-politics. Smartness could enhance the scope of governance by embracing new alternatives offered by the urban commons (Oström, 2010) and by avoiding narrow-minded public-private partnership finance schemes. Cities that become collections of urban laboratories would require an active ecosystem of stakeholders to function as a living metabolism. Triple and quadruple helix models have so far advocated fixed inter-institutional relationships, which is why this active ecosystem of stakeholders requires a fifth element - the entrepreneurial blood of the metabolism. Ultimately, this is the only way in which cities could be presented as a realm where citizens act and live as decision makers contributing to a maker production culture.

This type of experimentalism resonates with entrepreneurial models of socioeconomic systems which have been implemented in different parts of the world, some of which have been heavily researched. The Mondragon co-operative (Calzada, 2013a) is a paradigmatic model that includes the penta helix multi-stakeholder framework at the 
regional level. It is a source of territorial development and social cohesion. Nevertheless, even this model is showing some inherent contradictions that require further critical analysis. Actually, Mondragon co-operatives are facing some years ago two complementary crises. On the one hand, the pressure of the global markets is undermining the cohesive model based on local employement, as the crisis in Fagor flagship firm showed some years ago. On the other hand, as a consequence of the first one, the governance model seems to depict a hierarchical conflict between the top management and the workers. Although the most substantial lesson learnt (Calzada, 2013a) is unresolved yet: how to update and re-activate the regionally-rooted cooperative principles and values in the XXI century? By refounding a new type of cooperative entrepreneurship based on start-ups and spin-offs? Which could be set up by networked-driven millennials/entrepreneurs under open innovation solid, sustainable but strongly-fixed organizational structural schemes? To sum up, an updated urban cooperative version based on inter-dependent metropolitan inclusiveness and regionallyrooted social capital.

At the end of this chapter, I dare to question whether or not the establishment of an ecosystem of urban co-operatives could form a radical alternative towards experimental cities (Ratner, 2009; 2013; 2015). Some of the hypothesis presented in this chapter (including the evolution of citizens as decision makers, increasing awareness of its techno-political implications, increasing interdependence between stakeholders, and the trend toward urban laboratories) seem to create pathways toward urban cooperatives in energy, mobility, and ICTs - three sectors where the smart city approach is developing increasingly more sophisticated business models.

Hence, to conclude this chapter, I will shortly reply to the preliminary research questions asked in the first section: 
1. What prospects are there for alternative funding and alternative business models for smart/experimental cities?

In the current experimental realm, the way in which some urban solutions are modifying the ownership of capital (and in parallel, different assumptions of who owns data) could offer interesting pathways to set up alternative funding and alternative business models based on the experience of some socioeconomic models like co-operative firms.

2. What are the practical/political interventions needed among businesses, local governments, academia, communities, and social entrepreneurs?

It is remarkable the way some businesses are setting up an ecosystem of entrepreneurial small and medium-sized enterprises (SMEs). Territorial strategic alliances present a key ingredient for boosting a new generation of economic activity driven by the urban commons.

3. Is another type of (smart) city possible - that is, a third-way between the state and market overcoming public-private partnerships (PPP)?

So far, PPP have been the primary model reinforcing the alliance between the state and market. However, in some cities and regions such as Barcelona, Bristol, Glasgow, Bilbao, and Dublin (Calzada, 2017a), we see that the right balance and common strategy formed between public institutions, private firms, academia, civil society, and entrepreneurs/activists (i.e., the penta helix framework) is likely to open up a third-way led by urban co-operatives under the urban laboratories open scheme - a model that sooner or later will become a paradigmatic model to follow. 


\section{References}

Albino, V., Berardi, U. \& Dangelico, R. M. (2015). Smart Cities: Definitions, Dimensions, Performance, and Initiatives, Journal of Urban Technology, 22(1), 3-21. doi: 10.1037/1065-9293.59.3.209

Almirall, E. \& Wareham, J. (2011). Living Labs: arbiters of mind- and ground-level innovation, Technology Analysis \& Strategic Management, 23(1), 87-102. doi: 10.1080/09537325.2011.537110.

Amin, A. \& Thrift, N. (2016). Seeing Like a City. London: Polity.

Anttiroiko, A., Valkama, P. \& Bailey, S. J. (2013). Smart Cities in the new service economy: building platforms for smart cities, $A I \& S o c, 29,323-334$. doi: 10.1007/s00146-013-0464-0.

Anttiroiko, A. (2016). City-as-a-platform: Towards citizen-centre platform governance, presented at the RSA Winter Conference 2016 on New Pressures on Cities and Regions, 24-25 November, London, UK.

BITS, Barcelona Initiative for Technological Sovereignty (2016). Retrieved from https://bits.city/

Bollier, D. \& Helfrich, S (2016). Patterns of Commoning, The Commons Strategies Group. Retrieved from http://bollier.org/blog/spanish-translation\%E2\%80\%9Cthink-commoner\%E2\%80\%9D-now-published

Bollier, D. (2016). The City as a Commons. Retrieved from https://www.youtube.com/watch?v=z3itmhDuem8 (2016)

Borch, C. \& Kornberger, M. (2015). Urban Commons: Rethinking the City. London: Routledge.

Calzada, I. (2017b). Transforming Smart Cities with Social Innovation: Penta Helix Multi-Stakeholders Framework, presented in the SS21 Beyond Smart \& DataDriven City-Regions? Rethinking Stakeholder-Helixes Strategies, in the RSA Annual Conference 2017, 6th June, Dublin, Ireland..

Calzada, I. (2017a). The Techno-Politics of Data and Smart Devolution in CitiesRegions: Comparing Glasgow, Bristol, Barcelona, and Bilbao. Systems, 5(1), 18. doi: 10.3390/systems5010018. Retrieved from http://www.mdpi.com/2079$\underline{8954 / 5 / 1 / 18}$

Calzada, I. (2016). (Un)Plugging Smart Cities with Urban Transformations: Towards Multistakeholder City-Regional Complex Urbanity? URBS, Revista de Estudios Urbanos y Ciencias Sociales Journal, 6(2), 25-45. Retrieved from http://www2.ual.es/urbs/index.php/urbs/article/view/calzada

Calzada, I. \& Cobo, C. (2015). Unplugging: Deconstructing the Smart City. Journal of Urban Technology, 22(1): 23-43. doi: 10.1080/10630732.2014.971535. 
Calzada, I. (2015). Benchmarking Future City-Regions Beyond Nation-States. Regional Studies Regional Science, 2(1): 350-361. doi: 10.1080/21681376.2015.1046908.

Calzada, I. (2013b). Critical Social Innovation in the Smart City era for a City-Regional European Horizon 2020. Journal of Public Policies \& Territory P3T, 2(6): 1-20.

Calzada, I. (2013a). Knowledge Building \& Organizational Behaviour: Mondragon Case. In F. Moulaert, D. MacCallum, A. Mehmood and A. Hamdouch (Eds.), International Handbook of Social Innovation. Social innovation: Collective action, Social learning and Transdisciplinary research (pp. 219-229). Cheltenham, UK and Northampton, MA, USA: Edward Elgar Publishing. doi: 10.13140/RG.2.2.30748.69766.

Campbell, T. (2006). Beyond Smart Cities: How Cities Network, Learn and Innovate. Oxon: Earthscan.

Casual Synthesis report (2016). Co-creating Attractive and Sustainable Urban Areas and Lifestyles: Exploring new forms of inclusive urban governance, Nordregio \& JPI Urban Europe.

City of Things (2016). Discover today the possibilities of tomorrow's smart cities. Retrieved from https://www.iminds.be/en/succeed-with-digital-research/go-tomarket-testing/city-of-things

CNN (2016). Yinchuan smart city future. Retrieved from http://edition.cnn.com/2016/10/10/asia/yinchuan-smart-city-future

Ersoy, A. (2017). Smart cities as mechanism towards a broader understanding of infrastructure interdependencies. Regional Studies, Regional Science, 4(1): 1-6 doi: $10.1080 / 21681376.2017 .1281154$.

European Commission-H2020 (2017). SCC1 Clustering Meeting Minutes on $24^{\text {th }}$ March 2017, Nottingham.

Evans, J., A. Karvonen \& R. Raven (2017). Experimental City. London and New York: Routledge.

Finn, E., (2017). What Algorithms Want: Imagination in the Age of Computing. Cambridge, Massachusetts and London, England: The MIT Press.

Flamenco Project (2016). Flanders Mobile Enacted Citizen Observatories. Retrieved from www.citizen-observatory.be

Forbes (2016). Cities cannot be reduced to just big data and IoT: Smart City Lessons From Yinchuan, China. Retrieved from http://www.forbes.com/sites/federicoguerrini/2016/09/19/engaging-citizens-orjust-managing-them-smart-city-lessons-from-china/\#6a5a34392dda

Foster, S. \& Iaione, C. (2016). The City as a Commons. Yale Law \& Policy Review, 34 (2): 2. Retrieved from http://digitalcommons.law.yale.edu/ylpr/vol34/iss2/2 
Gartner (2016). Gartner Says Smart Cities Will Use 1.6 Billion Connected Things in 2016. Retrieved from http://www.gartner.com/newsroom/id/3175418

Giorgino, V. (2014). Contemplative Methods Meet Social Sciences: Back to Human Experience as It Is. Journal for the Theory of Social Behaviour, 45(4). doi: $10.1111 /$ jtsb.12078.

Gray, J. \& Lämmerhirt, D. (2017). Data and The City: How Can Public Data Infrastructures Change Lives in Urban Regions. Cambridge: Open Knowledge.

Latour, B. (1983). Give me a laboratory and I will raise the world. in Science observed: perspectives on the social study of science. In K. Knorr-Cetina and M. Mulkay. London: Sage Publications.

Leminen, S. (2015). Living Labs as Open Innovation Networks: Networks, Roles and Innovation Outcomes. Doctoral Dissertations 132/2015.

Leydesdorff, L., \& Fritsch, M. (2006). Measuring the Knowledge Base of Regional Innovation Systems in Germany in terms of a Triple Helix Dynamics. Research Policy, 35(10): 1538-1553.

Lewontin, R. (2000). The Triple Helix: Gene, Organism, and Environment. Cambridge, MA/London: Harvard University Press.

Habermas, J. (2015). The lure of technocracy. New York, USA: Polity Press.

Hackair Project (2016). Collective Awareness for Air Quality. Retrieved from www.hackair.eu

Hajer, M. \& Dassen, T. (2015). Smart about cities: visualising the challenge for 21st Century Urbanism. Amsterdam: naio19 publishers/pbl.

Harari, Y. (2016). Yuval Noah Harari on big data, Google and the end of free will. Retrieved from https://www.ft.com/content/50bb4830-6a4c-11e6-ae5ba $7 \mathrm{cc} 5 \mathrm{dd} 5 \mathrm{a} 28 \mathrm{c}$

Hemment, D. \& Townsend, A. (2013). Smart Citizens. Manchester: FutureEverything.

Herrschel, T. \& Dierwechter, Y. (2016). Smart City-Regional Governance: A 'dual transition, Regions, 300 (4): 20-21. doi:10.1080/13673882.2015.11668693.

Hughes, B. (2016). The Bleeding Edge: Why Technology Turns Toxix in an Unequal World. London: New Internationalist.

Karvonen, A. \& van Heur, B (2014). Urban Laboratories: Experiments in Reworking Cities. International Journal of Urban and Regional Research, 38(2): 379-392.

Keith, M. \& Calzada, I. (2016). European Smart Citizens as Decision Makers Rather Thank Data Providers, Urban Transformations ESRC report on 14th November 
2016 Workshop entitled '(Un)Plugging Data in Smart City-Regions'. doi: 10.13140/RG.2.2.11175.14240.

Keith, M. \& Headlam, N. (2016). The Urban Living Global Challenge: A Prospectus. Comparative International Exemplars Urban and Living Labs.

Kitchin, R. (2016). Reframing, Reimagining and Remaking Smart Cities. The Programmable City Working Paper 20.

Kontokosta, C. E. (2016). The Quantified Community and Neighbourhood Labs: A Framework for Computational Urban Science and Civic Technology Innovation. Journal of Urban Technology, 23(4), 67-84. doi: 10.1080/10630732.2016.1177260.

Krivy, M., (2016). Towards a critique of cybernetic urbanism: The smart city and the society of control. Planning Theory, 1-23.

Marvin, S., Luque-Ayala, A. and McFarlane, C. (2015). Smart Urbanism: Utopian Vision or False Dawn? London: Routledge.

Marwick, A. \& Boyd, D. (2010). I Tweet Honestly, I Tweet Passionately: Twitter Users, Context Collapse, and the Imagined Audience. New Media \& Society. doi: $10.1177 / 1461444810365313$.

McCullough, M. (2013). Ambient Commons: Attention in the Age of Embodied Information, Massachussets: The MIT Press.

Morozov, E. (2014). The rise of data and the death of politics. Retrieved from https://www.theguardian.com/technology/2014/jul/20/rise-of-data-death-ofpolitics-evgeny-morozov-algorithmic-regulation

Morozov, E. \& Harvey, D. (2016). Conversation between Evgeny Morozov and David Harvey. Retrieved from http://davidharvey.org/2016/11/video-conversationbetween-david-harvey-evgeny-morozov-on-post-neoliberalism-trumpinfrastructure-sharing-economy-smart-city/

Morozov, E. \& Bria, F. (2017). Roundtable Session - A New Deal on Data: What role for Cities? Smart City Expo World Congress. Retrieved from https://www.youtube.com/watch?v=1 cakaaip2 Vw

Morozov, E. \& Eno, B. (2017). Debat. Brian Eno i Evgeny Morozov Una conversa sobre tecnologia i democràcia. Retrieved from https://vimeo.com/206060710

NESTA. (2015). Data for Good: How Big and Open Data can be used for the common good.

Noveck, S. (2015). Smart Citizens, Smarter State: The Technologies of Expertise and the Future of Governing. Boston: Harvard University Press. 
OECD/KIPF (2016). Fiscal Federalism 2016: Making Decentralisation Work. 2016. Paris: $\quad$ OECD $\quad$ Publishing. $\quad$ Retrieved from http://dx.doi.org/10.1787/9789264254053-en

Oström, E. (2010). Beyond Markets and States: Polycentric Governance of Complex Economic Systems. American Economic Review 100. 1-33.

PWC (2016). From concept to applied solutions: Data-driven cities.

Ratner, C. (2009). Cooperativism: A Social, Economic, and Political Alternative to Capitalism. Capitalism Nature Socialism, 20(2): 44-73.

Ratner, C. (2013). Cooperation, Community, and Co-ops in A Global Era. NY: Springer.

Ratner, C. (2015). The Politics of Cooperation and Co-ops: Forms of Cooperation and Co-ops, and the Politics That Shape Them. NY: Nova Publishers.

Ratti, C. and Claudel, M. (2016). The City of Tomorrow: Sensors, Networks, Hackers, and the Future of Urban Life. New Haven and London: Yale University Press.

Rossi, U., (2015). The Variegated Economics and the Potential Politics of the Smart City. Territory, Politics, Governance, 4(3): 337-353. doi: 10.1080/21622671.2015.1036913.

Sabato, S., Vanhercke, B. \& Verschraegen, G. (2017). Connecting entrepreneurship with policy experimentation? The EU framework for social innovation. Innovation: The European Journal of Social Science Research, 30(2): 147-167 doi: 10.1080/13511610.2017.1282308.

Satyam, A. \& Calzada, I. (2017). The Smart City Transformations. New Delhi: Bloomsbury Academic and Professional Publishing.

Schuurman, D., De Marez, L. \& Ballon, P. (2016). The Impact of Living Lab Methodology on Open Innovation Contributions and Outcomes. Technology Innovation Management Review, 1(6): 7-16. Retrieved from http://timreview.ca/article/956

Shilton, K. (2016). When They Are Your Big Data: Participatory Data Practices as a Lens on Big Data. In C. Sugimoto, H. Ekbia, \& M. Mattioli. Big Data is Not a Monolith. Massachussets: MIT Press.

Subirats, J. (2012). The Commons: Beyond the market vs. state dilemma. Open Democracy. Retrieved from https://www.opendemocracy.net/joansubirats/commons-beyond-market-vs-state-dilemma

Thomas, V., Wang, D., Mullagh, L. \& Dunn, N. (2016). Where's Wally? In Search of Citizen Perspectives on the Smart City. Sustainability, 8(3): 207. doi: 10.3390/SU8030207. 
Uraia Nicosia Guidelines (2016). The Impact of Smart Technologies in the Municipal Budget: Increased Revenue and Reduced Expenses for Better Services.

Waag (2016). A Manifesto for Smart Citizens. Retrieved from http://waag.org/en/blog/manifesto-smart-citizens

West, J. \& Bogers, M. (2016). Open innovation: current status and research opportunities. Innovation 19(1): 43-50. doi: 10.1080/14479338.2016.1258995. 